\title{
Front Matter: Volume 8705
}

, "Front Matter: Volume 8705," Proc. SPIE 8705, Thermosense: Thermal Infrared Applications XXXV, 870501 (4 June 2013); doi: 10.1117/12.2031915

SPIE Event: SPIE Defense, Security, and Sensing, 2013, Baltimore, Maryland, SPIE. United States 


\section{PROCEEDINGS OF SPIE}

\section{Thermosense: Thermal Infrared Applications XXXV}

Gregory R. Stockton

Fred P. Colbert

Editors

30 April-1 May 2013

Baltimore, Maryland, United States

Sponsored and Published by

SPIE 
The papers included in this volume were part of the technical conference cited on the cover and title page. Papers were selected and subject to review by the editors and conference program committee. Some conference presentations may not be available for publication. The papers published in these proceedings reflect the work and thoughts of the authors and are published herein as submitted. The publisher is not responsible for the validity of the information or for any outcomes resulting from reliance thereon.

Please use the following format to cite material from this book:

Author(s), "Title of Paper," in Thermosense: Thermal Infrared Applications XXXV, edited by

Gregory R. Stockton, Fred P. Colbert, Proceedings of SPIE Vol. 8705 (SPIE, Bellingham, WA, 2013) Article CID Number.

ISSN: 0277-786X

ISBN: 9780819494962

Published by

SPIE

P.O. Box 10, Bellingham, Washington 98227-0010 USA

Telephone +1 3606763290 (Pacific Time) · Fax +1 3606471445

SPIE.org

Copyright (C) 2013, Society of Photo-Optical Instrumentation Engineers.

Copying of material in this book for internal or personal use, or for the internal or personal use of specific clients, beyond the fair use provisions granted by the U.S. Copyright Law is authorized by SPIE subject to payment of copying fees. The Transactional Reporting Service base fee for this volume is $\$ 18.00$ per article (or portion thereof), which should be paid directly to the Copyright Clearance Center (CCC), 222 Rosewood Drive, Danvers, MA 01923. Payment may also be made electronically through CCC Online at copyright.com. Other copying for republication, resale, advertising or promotion, or any form of systematic or multiple reproduction of any material in this book is prohibited except with permission in writing from the publisher. The CCC fee code is 0277-786X/13/\$18.00.

Printed in the United States of America.

Publication of record for individual papers is online in the SPIE Digital Library.

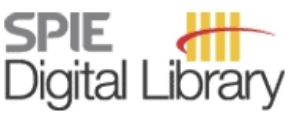

SPIEDigitalLibrary.org

Paper Numbering: Proceedings of SPIE follow an e-First publication model, with papers published first online and then in print and on CD-ROM. Papers are published as they are submitted and meet publication criteria. A unique, consistent, permanent citation identifier (CID) number is assigned to each article at the time of the first publication. Utilization of CIDs allows articles to be fully citable as soon as they are published online, and connects the same identifier to all online, print, and electronic versions of the publication. SPIE uses a six-digit CID article numbering system in which:

- The first four digits correspond to the SPIE volume number.

- The last two digits indicate publication order within the volume using a Base 36 numbering

system employing both numerals and letters. These two-number sets start with 00, 01, 02, 03, 04, $05,06,07,08,09,0 A, 0 B \ldots$. 0Z, followed by 10-1Z, 20-2Z, etc.

The CID Number appears on each page of the manuscript. The complete citation is used on the first page, and an abbreviated version on subsequent pages. Numbers in the index correspond to the last two digits of the six-digit CID Number. 


\title{
Contents
}

\author{
ix Conference Committee \\ xiii Introduction \\ xv Dedication: Sven-Åke Ljingberg and Ermanno G. Grinzato
}

\section{SESSION 1 BUILDING APPLICATIONS}

870502 Thermographic analysis of the thermal properties of wood for wooden windows [8705-2] P. Bison, A. Bortolin, G. Cadelano, G. Ferrarini, Istituto per le Tecnologie della Costruzione, CNR (Italy); S. Laguela Lopez, Univ. of Vigo (Spain); F. Peron, IUAV Univ. (Italy)

870503 High-resolution survey of buildings by lock-in IR thermography [8705-3]

A. Bortolin, G. Cadelano, G. Ferrarini, P. Bison, Istituto per le Tecnologie della Costruzione, CNR (Italy); F. Peron, IUAV Univ. (Italy); X. Maldague, Univ. Laval (Canada)

870504 The case for using a sacrificial layer of absorbent insulation in the design of flat and lowsloped roofing [8705-4]

G. R. Stockton, Stockton Infrared Thermographic Services, Inc. (United States)

870505 Methods to attack or defend the professional integrity and competency of infrared thermographers and their work; what every attorney and infrared thermographer needs to know before going into a lawsuit [8705-5]

F. Colbert, Colbert Infrared Services (United States), The Professional Thermographers Association (United States) and Thermal Trend (United States)

870506 In-situ calibration of a microbolometer camera for the study of large-scale fires [8705-1] J. de Vries, FM Global (United States)

870507 Flow detection via sparse frame analysis for suspicious event recognition in infrared imagery [8705-6]

H. C. Fernandes, Laval Univ. (Canada); M. A. Batista, Federal Univ. of Goias (Brazil);

C. A. Z. Barcelos, Federal Univ. of Uberlandia (Brazil); X. P. V. Maldague, Laval Univ. (Canada)

870508 Standoff laser-induced thermal emission of explosives [8705-7]

N. Y. Galán-Freyle, L. C. Pacheco-Londoño, A. Figueroa-Navedo, S. P. Hernandez-Rivera, Univ. of Puerto Rico-Mayagüez (United States)

870509 Analysis of the ballistic impact response of a composite material using FAST Infrared Imagery [8705-8]

F. Marcotte, Telops, Inc. (Canada); S. Ouellet, Defence Research and Development

Canada, Valcartier (Canada); V. Farley, Telops, Inc. (Canada) 
8705 0A Analysis of dust cloud combustion using FAST Infrared Imaging [8705-9]

F. Marcotte, V. Farley, S. Savary, Telops, Inc. (Canada)

\section{SESSION 3 SECURITY II}

$8705 \mathrm{OB} \quad$ Fusion of active and passive infrared images for face recognition [8705-10] M. A. Akhloufi, A. Bendada, Laval Univ. (Canada)

8705 0C A multistep approach for infrared face recognition in texture space [8705-11] M. A. Akhloufi, A. Bendada, Laval Univ. (Canada)

8705 OD Improved detection of highly energetic materials traces on surfaces by standoff laserinduced thermal emission incorporating neural networks [8705-37]

A. Figueroa-Navedo, N. Y. Galán-Freyle, L. C. Pacheco-Londoño, S. P. Hernández-Rivera, Univ. de Puerto Rico Mayagüez (United States)

\section{SESSION 4 RESEARCH AND DEVELOPMENT}

8705 OE Compact high-speed MWIR spectrometer applied to monitor $\mathrm{CO}_{2}$ exhaust dynamics from a turbojet engine [8705-12]

R. Linares-Herrero, G. Vergara, R. Gutiérrez Álvarez, C. Fernández Montojo, L. J. Gómez, V. Villamayor, A. Baldasano Ramírez, M. T. Montojo, New Infrared Technologies, S.L. (Spain); V. Archilla, A. Jiménez, D. Mercader, Instituto Nacional de Técnica Aeroespacial (Spain);

A. González, A. Entero, ISDEFE (Spain)

8705 OF Design of a Remote Infrared Images and Other Data Acquisition Station for outdoor applications [8705-13]

M.-A. Béland, F. B. D. Djupkep, A. Bendada, X. Maldague, Univ. Laval (Canada);

G. Ferrarini, P. Bison, E. Grinzato, Istituto per le Tecnologie della Costruzione, CNR (Italy)

8705 OG Infrared thermography inspection of glass reinforced plastic (GRP) wind turbine blades and the concept of an automated scanning device [8705-14]

N. P. Avdelidis, C. Ibarra-Castanedo, X. P. V. Maldague, Univ. Laval (Canada)

\section{SESSION $5 \quad$ MEDICAL}

$8705 \mathrm{OH} \quad$ Experimental model for determining developmental stage of chicken embryo using infrared images and artificial neural networks [8705-16]

S. K. Jung, Univ. of California, Berkeley (United States); S.-J. Hsieh, C.-H. Chen, Texas A\&M Univ. (United States)

8705 Ol Thermal imaging to detect physiological indicators of stress in humans [8705-17]

C. B. Cross, J. A. Skipper, D. T. Petkie, Wright State Univ. (United States) 
8705 OK Thermographic in-situ process monitoring of the electron-beam melting technology used in additive manufacturing [8705-19]

R. B. Dinwiddie, R. R. Dehoff, P. D. Lloyd, L. E. Lowe, Oak Ridge National Lab. (United

States); J. B. Ulrich, Oak Ridge Institute for Science and Education (United States)

$8705 \mathrm{OL}$ Real-time process monitoring and temperature mapping of a 3D polymer printing process [8705-20]

R. B. Dinwiddie, L. J. Love, J. C. Rowe, Oak Ridge National Lab. (United States)

$87050 \mathrm{M}$ Thermal imaging for assessment of electron-beam freeform fabrication (EBF ${ }^{3}$ ) additive manufacturing deposits (Invited Paper) [8705-21]

J. N. Zalameda, E. R. Burke, R. A. Hafley, K. M. B. Taminger, C. S. Domack, A. Brewer,

R. E. Martin, NASA Langley Research Ctr (United States)

\section{SESSION 7 MATERIALS EVALUATION}

8705 OP Crack detection using induction thermography during high-temperature testing [8705-22] M. Genest, D. C. Dudzinski, National Research Council Canada (Canada); L. Dawag, R. K. Kersey, Pratt \& Whitney (United States)

\section{SESSION 8 NDT (NONDESTRUCTIVE TESTING) I}

$87050 Q \quad$ Nondestructive inspection in adhesive-bonded joint CFRP using pulsed phase thermography [8705-25]

P. H. Shin, S. C. Webb, K. J. Peters, North Carolina State Univ. (United States)

8705 OR Non-visible defect detection in glass using infrared thermography and artificial neural networks [8705-26]

A. Campa, Boston Univ. (United States); S. J. Hsieh, H. J. Wang, Texas A\&M Univ. (United States)

\section{SESSION 9 NDT (NONDESTRUCTIVE TESTING) II}

8705 OS Comparison of pulse phase and thermographic signal reconstruction processing methods [8705-27]

B. Oswald-Tranta, Univ. of Leoben (Austria); S. M. Shepard, Thermal Wave Imaging, Inc. (United States)

8705 OT Evaluating quality of adhesive joints in glass-fiber plastic piping by using active thermal NDT [8705-28]

M. Grosso, Univ. Federal do Rio de Janeiro (Brazil); C. A. Marinho, Petrobras Research Center (Brazil); D. A. Nesteruk, Tomsk Polytechnic Univ. (Russian Federation);

J. M. A. Rebello, Univ. Federal do Rio de Janeiro (Brazil); S. D. Soares, Petrobras Research Ctr. (Brazil); V. P. Vavilov, Tomsk Polytechnic Univ. (Russian Federation) 
$8705 \mathrm{OU}$ Nondestructive testing of externally reinforced structures for seismic retrofitting using flax fiber reinforced polymer (FFRP) composites [8705-29]

C. Ibarra-Castanedo, Laval Univ. (Canada); S. Sfarra, D. Paoletti, Univ. of L'Aquila (Italy);

A. Bendada, X. Maldague, Laval Univ. (Canada)

$87050 \mathrm{~V}$ Improved sizing of impact damage in composites based on thermographic response [8705-30]

W. P. Winfree, P. A. Howell, C. A. C. Leckey, M. D. Rogge, NASA Langley Research Ctr. (United States)

$8705 \mathrm{OW} \quad$ Analysis of signal processing techniques in pulsed thermography [8705-31]

F. Lopez, Univ. Federal de Santa Catarina (Brazil); C. Ibarra-Castanedo, X. Maldague, Univ. Laval (Canada); V. de Paulo Nicolau, Univ. Federal de Santa Catarina (Brazil)

8705 0X Detection of defects in laser powder deposition (LPD) components by pulsed laser transient thermography [8705-32]

S. P. Santospirito, K. Styk, B. Luo, Kingston Computer Consultancy Ltd. (United Kingdom);

R. Łopatka, Polkom Badania (Poland) and Warsaw Univ. of Technology (Poland);

O. Gilmour, J. Rudlin, TWI Ltd. (United Kingdom)

8705 OY Nondestructive testing and evaluation of composites by non-invasive IR Imaging techniques [8705-33]

R. Mulaveesala, Indian Institute of Technology Ropar (India) and PDPM-Indian Institute of Information Technology Design and Manufacturing (India); J. A. Siddiqui, PDPM-Indian Institute of Information Technology Design and Manufacturing Jabalpur (India); V. Arora, Indian Institute of Technology Ropar (India); S. V. Ghali, K L Univ. (India) and PDPM-Indian Institute of Information Technology Design and Manufacturing (India); A. Muniyappa, PDPM-Indian Institute of Information Technology Design and Manufacturing Jabalpur (India); M. Takei, Graduate School of Chiba Univ. (Japan)

$87050 Z$ Theory, modeling, and simulations for thermal wave detection and ranging [8705-34] R. Mulaveesala, Indian Institute of Technology Ropar (India) and PDPM-Indian Institute of Information Technology Design and Manufacturing (India); S. V. Ghali, K L Univ. (India) and PDPM-Indian Institute of Information Technology Design and Manufacturing (India); V. Arora, Indian Institute of Technology Ropar (India); J. A. Siddiqui, A. Muniyappa, PDPMIndian Institute of Information Technology Design and Manufacturing Jabalpur (India); M. Takei, Graduate School of Chiba Univ. (Japan)

870510 Recent advances in thermal wave detection and ranging for non-destructive testing and evaluation of materials [8705-35]

R. Mulaveesala, Indian Institute of Technology Ropar (India) and PDPM-Indian Institute of Information Technology Design and Manufacturing Jabalpur (India); V. S. Ghali, K L Univ. (India) and PDPM-Indian Institute of Information Technology Design and Manufacturing Jabalpur (India); V. Arora, Indian Institute of Technology Ropar (India); J. A. Siddiqui, A. Muniyappa, PDPM-Indian Institute of Information Technology Design and Manufacturing Jabalpur (India); M. Takei, Graduate School of Chiba Univ. (Japan) 
870511 The zombie thermographer apocalypse preparedness 101: zombie thermographer pandemic [8705-36]

F. Colbert, Colbert Infrared Services (United States), Thermal Trend (United States) and The Professional Thermographers Association (United States)

Author Index 
Proc. of SPIE Vol. $8705870501-8$

Downloaded From: https://www.spiedigitallibrary.org/conference-proceedings-of-spie on 26 Apr 2023 Terms of Use: https://www.spiedigitallibrary.org/terms-of-use 


\section{Conference Committee}

Symposium Chair

Kenneth R. Israel, Major General (USAF Retired) (United States)

Symposium Cochair

David A. Whelan, Boeing Defense, Space, and Security (United States)

Conference Chair

Gregory R. Stockton, Stockton Infrared Thermographic Services, Inc.

(United States)

Conference Cochair

Fred P. Colbert, Colbert Infrared Services (United States)

Conference Program Committee

Andrea Acosta, Colbert Infrared Services (United States)

Nicolas P. Avdelidis, National Technical University of Athens (Greece)

Jeff R. Brown, Hope College (United States)

Douglas Burleigh, La Jolla Cove Consulting (United States)

K. Elliott Cramer, NASA Langley Research Center (United States)

Ralph B. Dinwiddie, Oak Ridge National Laboratory (United States)

Sheng-Jen "Tony" Hsieh, Texas A\&M University (United States)

Herbert Kaplan, Honeyhill Technical Co. (United States)

Timo T. Kauppinen, VTT Technical Research Center of Finland (Finland)

Dennis H. LeMieux, Siemens Power Generation, Inc. (United States)

Monica Lopez Saenz, IRCAM GmbH (Germany)

Xavier P. V. Maldague, University Laval (Canada)

Gary L. Orlove, FLIR Systems, Inc. (United States)

G. Raymond Peacock, Temperatures.com, Inc. (United States)

Piotr Pregowski, Pregowski Infrared Services (Poland)

Ralph A. Rotolante, Vicon Infrared (United States)

Andres E. Rozlosnik, SI Termografía Infrarroja (Argentina)

Morteza Safai, The Boeing Co. (United States)

Takahide Sakagami, Kobe University (Japan)

Steven M. Shepard, Thermal Wave Imaging, Inc. (United States)

Sami Siikanen, VTT Technical Research Center of Finland (Finland)

Vladimir P. Vavilov, Tomsk Polytechnic University (Russian Federation) 
Xiong Yu, Case Western Reserve University (United States)

Joseph N. Zalameda, NASA Langley Research Center (United States)

Honored Members

Douglas Burleigh

K. Elliott Cramer

Timo T. Kauppinen

Xavier P. V. Maldague

Vladimir P. Vavilov

Emeritus Members

Herbert Kaplan

Robert Madding

G. Raymond Peacock

John R. Snell

Honored Late Members

Sven-Åke ljingberg

Lee R. Allen

Ermanno G. Grinzato

Session Chairs

1 Building Applications

Timo T. Kauppinen, VTT Technical Research Center of Finland (Finland)

Xavier P. V. Maldague, University Laval (Canada)

P1 Panel Discussion: Building

Timo T. Kauppinen, VTT Technical Research Center of Finland (Finland)

Xavier P. V. Maldague, University Laval (Canada)

2 Security I

Andres E. Rozlosnik, SI Termografía Infrarroja (Argentina)

Morteza Safai, The Boeing Co. (United States)

3 Security II

Andres E. Rozlosnik, SI Termografía Infrarroja (Argentina)

Morteza Safai, The Boeing Co. (United States)

P2 Panel Discussion: Security

Andres E. Rozlosnik, SI Termografía Infrarroja (Argentina)

Morteza Safai, The Boeing Co. (United States) 
4 Research and Development

Steven M. Shepard, Thermal Wave Imaging, Inc. (United States)

Xiong Yu, Case Western Reserve University (United States)

5 Medical

Nicolas P. Avdelidis, National Technical University of Athens (Greece)

Sheng-Jen "Tony" Hsieh, Texas A\&M University (United States)

P3 Panel Discussion: Medical

Nicolas P. Avdelidis, National Technical University of Athens (Greece)

Sheng-Jen "Tony" Hsieh, Texas A\&M University (United States)

T1 Tribute to Ermanno Grinzato and Sven Sven-Åke Ljungberg

Gregory R. Stockton, Stockton Infrared Thermographic Services, Inc. (United States)

Fred P. Colbert, Colbert Infrared Services (United States)

6 Additive Manufacturing

Ralph B. Dinwiddie, Oak Ridge National Laboratory (United States)

Joseph N. Zalameda, NASA Langley Research Center (United States)

7 Materials Evaluation

Joseph N. Zalameda, NASA Langley Research Center (United States)

Ralph B. Dinwiddie, Oak Ridge National Laboratory (United States)

P4 Panel Discussion: Additive Manufacturing and Materials Evaluation Joseph N. Zalameda, NASA Langley Research Center (United States) Ralph B. Dinwiddie, Oak Ridge National Laboratory (United States)

8 NDT (Nondestructive Testing) I

Vladimir P. Vavilov, Tomsk Polyłechnic University (Russian Federation) Dennis H. LeMieux, Siemens Power Generation, Inc. (United States)

9 NDT (Nondestructive Testing) II

Vladimir P. Vavilov, Tomsk Polytechnic University (Russian Federation) Dennis H. LeMieux, Siemens Power Generation, Inc. (United States)

P5 Panel Discussion: NDT (Nondestructive Testing)

Vladimir P. Vavilov, Tomsk Polytechnic University (Russian Federation)

Dennis H. LeMieux, Siemens Power Generation, Inc. (United States)

10 Professionalism

Gregory R. Stockton, Stockton Infrared Thermographic Services, Inc. (United States)

Fred P. Colbert, Colbert Infrared Services (United States) 
Proc. of SPIE Vol. $8705870501-12$

Downloaded From: https://www.spiedigitallibrary.org/conference-proceedings-of-spie on 26 Apr 2023 Terms of Use: https://www.spiedigitallibrary.org/terms-of-use 


\section{Introduction}

In 2012, we lost two great infrared thermographers and scientists with the passing of Sven-Åke Ljingberg in June and Ermanno G. Grinzato in August. I knew and very much respected the work of both of these fellows. When I first came to ThermoSense in the late 80s, I was in awe of Sven. He was showing helicopter infrared imagery. Imagine...flying around with infrared cameras! I was very much inspired by him. Ermanno was a thermographer's thermographer, and a great human being. We all miss him.

We continue to see big improvements in IR sensor technology with megapixel cameras going from $1 \times 1$ to $2 \times 2$ to $4 \times 4$. Hoorah! On the other end of the "spectrum", the low-cost infrared imagers are more popular than ever, with the prices falling quickly to the point where the training cost is more than the camera cost. This enviably means misuse of the technology, but I tend to look at it in a different way: Every time the price drops to a new lower level that means whole new markets open up and whole new groups of people begin to use infrared technology! It is the job of ThermoSense to offer people a place to learn about thermography applications at the highest level. I believe we have done that very well in the past, and will continue to do so well into the future.

It has been a great privilege to serve as Chairman. I would like to thank the Session Chairs and my Co-Chair Fred Colbert who spent their valuable time to organize the conference, review the papers and run the sessions. On their behalf, let me express the Program Committee's deepest appreciation to the authors who write and present their work freely, and without whom there would be no ThermoSense. Finally, I would like to thank the SPIE staff, who might not realize how much we appreciate the amount of work they do each year to make our great conference happen.

On behalf of the Program Committee, I am honored to present the Proceedings of ThermoSense XXXV.

Gregory R. Stockton 
Proc. of SPIE Vol. $8705870501-14$

Downloaded From: https://www.spiedigitallibrary.org/conference-proceedings-of-spie on 26 Apr 2023 Terms of Use: https://www.spiedigitallibrary.org/terms-of-use 


\section{Dedication_ Sven-Åke Ljingberg}

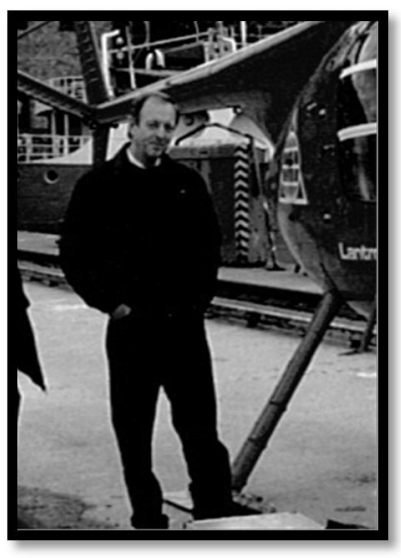

Sven-Åke Ljingberg passed away on June 14, 2012 after a battle with cancer. He was instrumental in the early development of SPIE Defense, Security, and Sensing (DSS), and the building of the AeroSense Conference.

He authored and submitted 15 papers starting with DSS 1989-2002, and served as a session chair 13 times, from 1992-2004.

Sven-Åke was always very positive and extremely dedicated, full of bright ideas, most of them were more than just ideas, he managed to bring them forward and produce good test results from them even if it sometimes seemed to be difficult and complicated.

He was always very nice to work with and never really complained even when we had big problems during the different development phases.

\section{- Jon Gawell}

He was my co-chair for the Building session for many years and was always a pleasure to work with, despite our geographical distance. I also believe he was the first international member of the steering committee outside of North America. In the years I was most active with Thermosense, I remember making a point of reaching out to the Europeans, and others, to expand the international claim Thermosense had. Sven was a big help in this matter, as I really had no idea what I was doing, only that I was trying.

He was always professional, punctual and reliable.

\section{- Sharon Allen Semanovich}

It was sorrowful to hear about my old colleague and good friend even though I knew about his illness. Sven-Åke is one of the most noticeable figures in the field of thermography.

\section{- Timo Kauppinen}


Sven-Åke Ljungberg was long absent at Thermosense due his illness and also because his father's illness. His headquarters was in Gävle in Northern Stockholm, Sweden. Sweden was one of the first countries to start with thermography and Sven-Åke one of its pioneers. All works on energy-saving and buildings were his field but also he always was on the leading edge in other diverse research topics. I learned a lot from him. He was already established at Thermosense when I started to participate at the conference.

He was a very warm person and was always willing to provide cooperation. One of the great figures of the early hours of Thermosense... a gentleman above all.

\section{- Andres E. Rozlosnik}

I remember Sven and Owe gathering around a piano and giving us an impromptu concert (Sven singing) during a consortium meeting near the Spadeadam test site in the North of England, in a hotel that happened to have a piano. I also remember him strumming his guitar in his on-site "accommodation" (a caravan?) on the Malmoe test site.

He was a lovely person to work with.

\section{- Jane Hodgkinson}




\section{Dedication_Ermanno G. Grinzato}

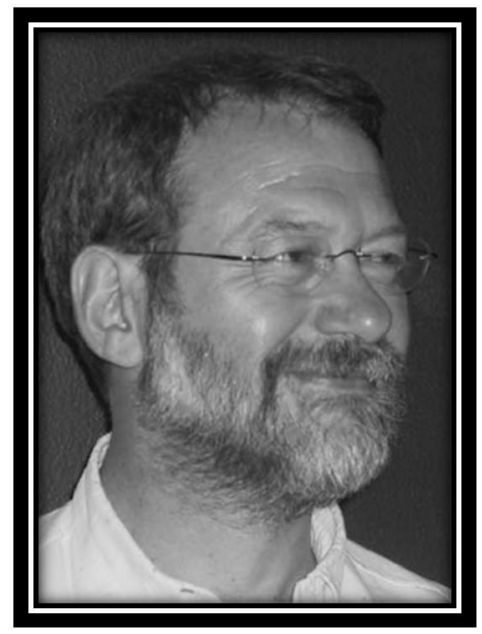

I regret to announce that Ermanno Grinzato passed away last night 21 August, 2012.

His illness prevailed in the last period but he was lucid until the end discussing of future works and giving advises on the things to do.

We lost an enthusiastic scientist and a friend.

- Paolo Bison

\section{http://www.qirt.org/image site/Grinzato obituary 2012.pdf}

From a personal point of view, he was a very amiable person, with a great sense of humor, especially in social life. He liked to pun with words and his brilliant mind amazed friends, sometimes highlighting unexpected aspects in the topic of discussion. It was remarkable his ability to motivate his collaborators, inspiring enthusiasm for new achievements and promoting new ideas, or as he used to say 'ideucce', pretty small ideas brought to his mind during the night.

He loved nature and to live in nature. He practiced equestrian sports and used to ride during the weekends. His ultimate desire was to be cremated and his ashes be scattered in the garden as humus for plants.

He is survived by his beloved wife Luciana and son Alessandro.

\section{- Paolo Bison}

Thermosense gave me a chance to meet Ermanno first in 1991. He invited me to visit shortly, his laboratory in Padua, and since that time my 'short' visit turned to be a multi-year collaboration with Ermanno and his colleagues Paolo Bison and Sergio Marinetti. As a matter of fact, I spent about 4 years in Italy densely collaborating with Ermanno. I looked into my list of publications and found that Ermanno was my co-author in about 40 papers.

I have always appreciated his scientific enthusiasm (I would even say his scientific curiosity) and professional features that made him an outstanding expert on IR thermography and its applications not only in Italy but worldwide. In fact, 
Ermanno was one of a few researchers who made Italy so noticeable on the map of IR thermography and thermal NDT. He contributed so much to NDT of art objects, thus bringing a spirit of Italian history to the contemporary technology.

It was an honor for me to be a guest at Ermanno's lovely house, to meet his wife Luciana and follow how his son Alessandro is growing up. I used to play lawntennis, table tennis and volley-ball with Ermanno for years. In Russia, we often say that death first takes over the best people. This is very true about Ermanno. It's hard to believe that we will not be meeting him at our international events. But people are with us as long as we remember them. Ermanno is "with us".

\section{- Vlad Vavilov}

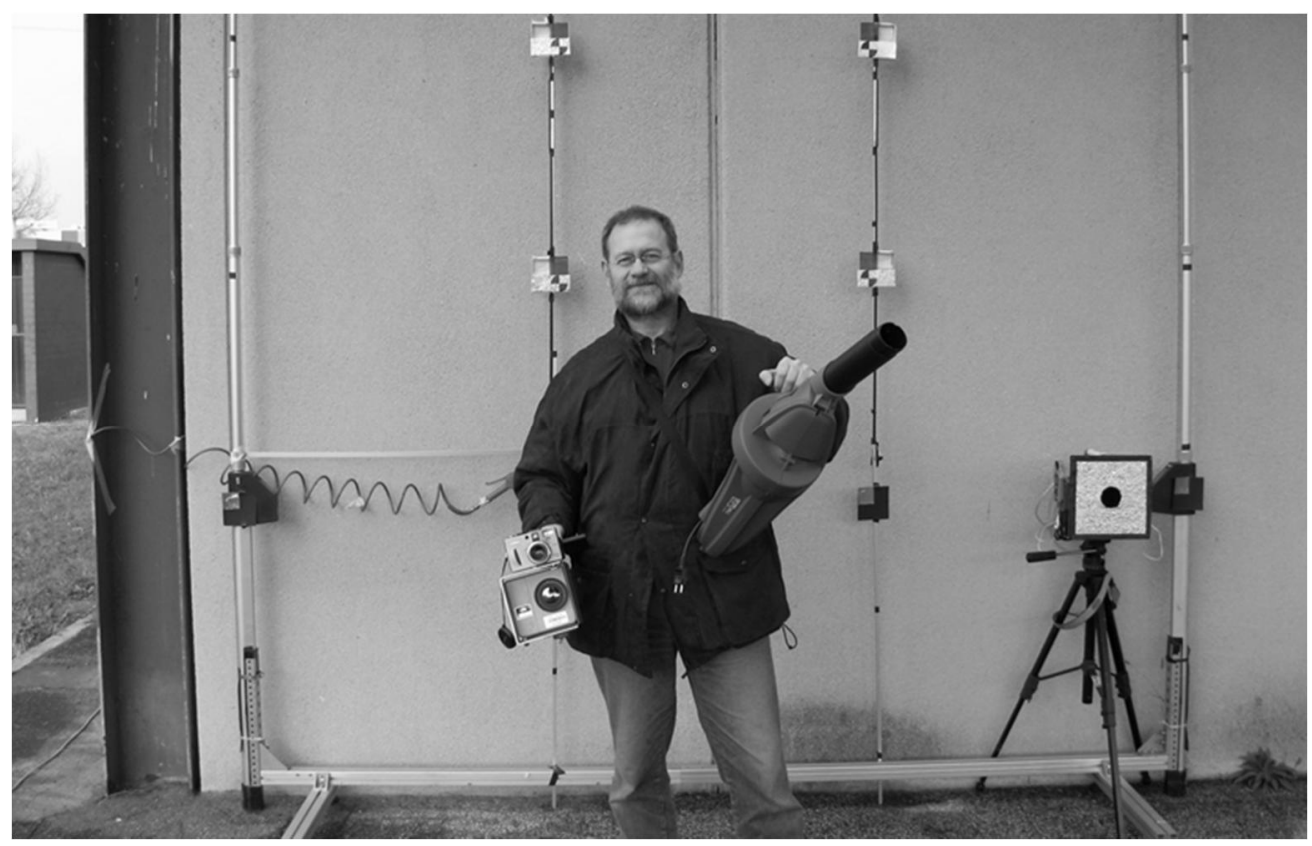

Ermanno presented many papers and has also collaborated as session chair on several occasions. Ermanno was a person who worked permanently keeping the conferences alive from his first participation from 1999-2000. He presented papers in many fields as a principal and secondary author. When Ermanno was listening to a paper in a particular session he always had an appropriate question for the author - no matter what the application was.

He was a very detailed person, very critical, a perfectionist, a highly-educated person. Not only have I shared time with Ermanno at Thermosense, but also in QIRT Europe, in Buenos Aires and in Patagonia Argentina (Neuquén). He did a great job of representing Italy. I have many stories with Ermanno maybe not only academic, but professional and personal. He was very full human being and professional person. Ermanno was a very friendly and kindly, sociable person also. 
His family and Italy must be very proud of him. His death is a hard thing to understand I regret I did not share other times with Ermanno. God took him too young.

\section{- Andres E. Rozlosnik}

Ermanno was an excellent scientist and a great person to talk to. I hope that God rest his soul.

\section{- Nico Avdelidis}

My deepest commiseration with Ermanno`s family and colleagues - I knew him almost 25 years and had great opportunity to work with him in Padova in 1995. We had continuous contacts dealing with thermography and it's applications.

\section{- Timo Kauppinen}

I was shocked at the sad news. It is unbelievable that Ermanno is no more on this Earth. I pray with my deepest condolences. I'll never forget his warm smile in our discussions. We lost a great lodestar in our research field and a friend. ... May his soul rest in peace.

\section{- Takahide Sakagami}

I'm very sorry to hear that Ermanno passed away. Please tell his family that he was a both a respected scientist and a friend to many of us in the IR/Thermosense community. He's been part of Thermosense for many (15-20) years. I had emailed Ermanno occasionally in recent months and was hoping his condition would improve. I'll miss him.

\section{- Doug Burleigh}

My deepest condolences go to Ermanno's family and colleagues at CNR-ITC and around the world. Ermanno was always a dedicated scientist in the area infrared thermography and brought out the best in his peers. He was no different in his personal life. I had the pleasure of knowing and working with him for over 26 years, and I shall forever treasure our times together along with the continuous correspondence through the years.

His kindness and integrity as a personal friend was shared with my family from the first time he traveled to Canada in 1986. My family and I are deeply saddened by this loss and send our regards to his family in Italy.

\section{- Tony Colantonio}


Proc. of SPIE Vol. $8705870501-20$

Downloaded From: https://www.spiedigitallibrary.org/conference-proceedings-of-spie on 26 Apr 2023 Terms of Use: https://www.spiedigitallibrary.org/terms-of-use 